\title{
Utility of Breath Ethane as a Noninvasive Biomarker of Vitamin E Status in Children
}

\author{
MAMDOUH REFAT, TARA J. MOORE, MANABU KAZUI, TERENCE H. RISBY,
} JAY A. PERMAN, AND KATHLEEN B. SCHWARZ

Departments of Pediatrics [M.R., T.J.M., J.A.P., K.B.S.] and Surgery [M.K.], Johns Hopkins University, School of Medicine, and Department of Environmental Health Sciences [T.H.R.], Johns Hopkins University, School of Public Health and Hygiene, Baltimore, Maryland 21205

\begin{abstract}
The purpose of our study was to determine if the ethane content of expired air could be a useful index of vitamin $\mathrm{E}$ status in children. Eight children with vitamin $\mathrm{E}$ deficiency secondary to chronic severe liver disease were studied: six of these children were treated with parenteral vitamin $\mathrm{E}(2-5 \mathrm{mg} / \mathrm{kg} /$ dose every 4-7 d). Measures of vitamin $\mathrm{E}$ status pre- and posttherapy were: serum vitamin $\mathrm{E}, 2 \pm 1$ versus $7 \pm 1 \mu \mathrm{g} / \mathrm{mL}(p<0.001)$; serum vitamin E:total lipids, $0.3 \pm 0.1$ versus $1.0 \pm 0.1 \mathrm{mg} / \mathrm{g}(p<0.001)$; and erythrocyte peroxide hemolysis test, $80 \pm 10$ versus 6 $\pm 12 \%(p<0.001)$. Fasting breath ethane in the patients pre- and posttherapy was $78 \pm 10$ versus $31 \pm 11 \mathrm{pmol} /$ $\mathrm{kg} / \mathrm{min}(p<0.001)$. Breath ethane correlated negatively with serum vitamin $\mathrm{E}(p<0.042)$ and serum E:total lipids $(p<0.004)$ and positively with the erythrocyte peroxide hemolysis test $(p<0.003)$. Values for treated patients did not differ from those for fasted sibling controls $(34 \pm 12$ $\mathrm{pmol} / \mathrm{kg} / \mathrm{min})$, postprandial sibling controls $(31 \pm 12 \mathrm{pmol} /$ $\mathrm{kg} / \mathrm{min}$ ), and healthy children sampled randomly, in the nonfasted state $(21 \pm 14 \mathrm{pmol} / \mathrm{kg} / \mathrm{min})$. Breath ethane production in one patient (up to $168 \mathrm{pmol} / \mathrm{kg} / \mathrm{min}$ ) did not normalize after treatment of vitamin $\mathrm{E}$ deficiency until her selenium deficiency was corrected as well. We conclude that this noninvasive test can be useful as a screen for vitamin $E$ deficiency in children and for ascertaining response to therapy. The presence of high concentrations of ethane in expired air in vitamin E-sufficient subjects may indicate deficiencies of other antioxidants such as selenium. (Pediatr Res 30: 396-403, 1991)
\end{abstract}

\section{Abbreviations}

HCFA, hydrocarbon free air

OVETT, oral vitamin E tolerance test

Vitamin $\mathrm{E}$ is the major lipid-soluble antioxidant in human plasma (1). Deficiency of this vitamin in experimental animals and in humans is accompanied by several measures of lipid peroxidation: increased erythrocyte thiobarbituric acid reactive substances (2), increased release of thiobarbituric acid reactive substances from erythrocytes after exposure to hydrogen peroxide (3), and increased breath ethane and pentane (4). These gases are the major volatile hydrocarbons that are generated through

Received November 1, 1990; accepted July 10, 1991.

Correspondence and reprint requests: Kathleen B. Schwarz, M.D., Department of Pediatrics, Johns Hopkins University, School of Medicine, Baltimore, MD 21205 .

Supported by a Johns Hopkins University Biological Research Support Grant (K.B.S.) and a U.S. AIDS Egyptian Peace Mission Fellowship (M.R.). K.B.S. is the recipient of a Johns Hopkins University Clinician Scientist Award. peroxidation of n-3 and n-6 fatty acids, respectively. Lemoyne et al. (5) have shown that treatment of vitamin E-deficient adults with i.v. vitamin $\mathrm{E}$ is associated with decreased pentane content of expired air. The utility of breath ethane or pentane analysis for the diagnosis of vitamin $E$ deficiency in pediatric patients has not been explored. Vitamin E deficiency, common in children with chronic severe liver disease, may cause progressive neurologic abnormalities unless treated $(6,7)$. Massive oral doses (100$200 \mathrm{IU} / \mathrm{kg}$ of water miscible vitamin E) may not correct the deficiency in this population, and parenteral vitamin $\mathrm{E}$ therapy may be necessary (8).

We analyzed the breath ethane content of children with severe vitamin $\mathrm{E}$ deficiency secondary to chronic liver disease to determine if there were differences between patients and controls, to observe the effect of parenteral vitamin E therapy, and to learn if there were correlations with standard measures of vitamin $E$ nutriture including serum vitamin $\mathrm{E}$, serum vitamin E:total lipids $(9,10)$, and the erythrocyte hydrogen peroxide hemolysis test (11).

\section{MATERIALS AND METHODS}

Subjects. Vitamin E deficiency was defined by serum vitamin E concentration $<5 \mu \mathrm{g} / \mathrm{mL}$ (normal $5-20 \mu \mathrm{g} / \mathrm{mL}$ ) and serum E:total lipids ratio $<0.6$ for children $<12$ y old and $<0.8$ for children 12 y and older (9). Eight children with chronic severe liver disease and vitamin E deficiency followed in the Pediatric Gastroenterology Clinic of the Johns Hopkins Children's Medical and Surgical Center were included in the study, after informed consent was obtained from the parents. The study was approved by the Joint Committee on Clinical Investigation of the Johns Hopkins Hospital.

The clinical characteristics of the patients are listed in Table 1. Patients $1-5,7$, and 8 had failed to normalize serum vitamin $E$ in response to large oral doses (up to $200 \mathrm{IU} / \mathrm{kg} / \mathrm{d}$ ) of watermiscible vitamin $\mathrm{E}$ (Aquasol $\mathrm{E}, d l-\alpha$-tocopheryl acetate) given for at least $1 \mathrm{y}$. Patient 6 had not been previously treated with vitamin E. Patients 1-6 were admitted to the Pediatric Clinical Research Unit for $5 \mathrm{~d}$, treated with intramuscular vitamin $\mathrm{E}$ as detailed below, and followed at intervals after discharge until normalization of vitamin E status. Patients 7 and 8 were sampled only once, on an outpatient basis. The healthy controls consisted of five siblings of the patients and four children not related to the patients; the disease controls were four children with chronic severe liver disease who were vitamin E-sufficient.

Study Protocol. In the inpatient studies, before vitamin E therapy, breath ethane was obtained before (fasting) and $2 \mathrm{~h}$ after a breakfast high in carbohydrate (60\% of total calories) or in fat ( $40 \%$ of total calories). Breath ethane and serum vitamin $E(12)$, total lipids $(9,10)$ and erythrocyte peroxide hemolysis (11) studies were obtained just before and 20 and $44 \mathrm{~h}$ after intramuscular administration of $\alpha$-tocopherol acetate (Hoffman LaRoche, Inc., 
Nutley, NJ). Serum vitamin $\mathrm{E}$ was analyzed by a microfluorometric technique (12); serum total lipids were assayed using the Boehringer Mannheim (Mannheim, Germany) Total Lipids Reagent Kit (10). These studies were also done at follow-up, during which children were receiving the specific dose of vitamin $E$ that produced a normal serum vitamin E:total lipids ratio when measured just before the next injection of vitamin $E$. In the sibling controls, blood samples were obtained once, after an overnight fast, and breath ethane was obtained after an overnight fast and $2 \mathrm{~h}$ after breakfast. In the healthy child controls and in the disease controls, random breath ethane samples were obtained once, in the nonfasted state.

Erythrocyte Peroxide Hemolysis (11). One $\mathrm{mL}$ of heparinized blood was transported on ice and immediately washed three times with normal saline, $\mathrm{pH} 7.4$, by centrifugation at $100 \times g$ (Damon/International Equipment Company centrifuge, Needham, MA) at $4^{\circ} \mathrm{C}$ for $10 \mathrm{~min}$. Subsequently, $0.250 \mathrm{~mL}$ of a $4 \%$ suspension of erythrocytes in $20 \mathrm{mM}$ PBS, $\mathrm{pH} 7.4$ was added to seven test tubes. Twenty-five hundredths of a mL of $2 \% \mathrm{H}_{2} \mathrm{O}_{2}$ (tubes 1-5) or PBS (tubes 6 and 7) was added to the erythrocyte suspension, and the mixture was incubated for $3 \mathrm{~h}$ at $37^{\circ} \mathrm{C}$. PBS $(4.5 \mathrm{~mL})$ was added to tubes $1-3$ (test) and tubes 6 and 7 (blank) Deionized water $(4.5 \mathrm{~mL})$ was added to tubes 4 and $5(100 \%$ hemolysis). Tubes were mixed well and centrifuged at $800 \times g$ at $4^{\circ} \mathrm{C}$ for $10 \mathrm{~min}$. The supernate was read at $510 \mathrm{~nm}$ (Beckman DU spectrophotometer, Fullerton, CA). Percentage of hemolysis was determined by the formula:

$$
\% \text { Hemolysis }=\frac{\mathrm{OD} \text { test }-\mathrm{OD} \text { blank }}{\mathrm{OD} 100 \% \text { hemolysis }- \text { OD blank }}
$$

OVETT. This test, modified from Sokol et al. (13), was performed on patient 5 , patient 6 , and on a "disease control" (a child with chronic active hepatitis and normal vitamin $E$ status) Serum vitamin $\mathrm{E}$ was measured before and at intervals after oral administration of $2000 \mathrm{IU}$ water-miscible vitamin $\mathrm{E}$. The vitamin E was administered on overnight fast. Patients were subsequently allowed to eat a normal hospital diet.

Breath Ethane. Breath collection. For a 4-min washout period, patients and controls inspired HCFA (3.8 parts per billion ethane; Linde Gases of Baltimore, MD). The HCFA was inspired through a face mask that was applied tightly over the nose and mouth and connected via a Rudolph valve to a gas-tight bag (Calibrated Instruments Inc., Hawthorne, NY) containing HCFA. Upon conclusion of the 4-min washout, a second bag (for collection of expired air) was connected to the Rudolph valve and HCFA was inspired for an additional $60 \mathrm{~s}$. The expired air obtained during this 60 -s collection constituted the sample for ethane determination.

Hydrocarbon gases were concentrated from the expired air samples on the same day of collection by vacuum aspiration through a desiccation cartridge (W. A. Hammond Drierite Co., Xenia, $\mathrm{OH}$ ) followed by a passage through soda lime to remove $\mathrm{CO}_{2}$ (14). The sample was subsequently aspirated through a coiled brass loop $(45 \mathrm{~cm} \times 3 \mathrm{~mm}$ inner diameter) packed with 6 $\mathrm{mL}$ Porasil-C (Alltech, Deerfield, IL) (mesh size 80-100 $\mu \mathrm{m}$ ) immersed in alcohol/liquid nitrogen and maintained at $-180^{\circ} \mathrm{C}$. At the end of concentration, the end of the loop closest to the collection bag was clamped. As the loop was slowly warmed, the opposite end of the loop was vented until the temperature reached $-120^{\circ} \mathrm{C}$. At that point, a gas-tight glass syringe was connected to the vented end of the loop and all gases released thereafter were withdrawn into the syringe. The loop was subsequently transferred to a $100^{\circ} \mathrm{C}$ heating bath and flushed with 10 $\mathrm{mL}$ of hydrocarbon-free nitrogen to remove any residual hydrocarbons. The total volume of concentrated gas collected (including the $10 \mathrm{~mL}$ "flush") is referred to as "vol samp" in the equation used to calculate ethane production detailed below.

Five $\mathrm{mL}$ of the concentrated samples were injected into a gas chromatograph (model 311 ; Carle, Loveland, $\mathrm{CO}$ ) equipped with a 1-mL sampling loop and a flame ionization detector. Hydrocarbon-free argon was used as the carrier gas at a flow rate of 30 $\mathrm{mL} / \mathrm{min}$, and the detection temperature for ethane was $40^{\circ} \mathrm{C}$. Hydrocarbons were eluted from a 2-m stainless steel column (Chromosorb 102; Alltech, Deerfield, IL). A typical chromatograph of a standard gas mix of methane and ethane is shown in Figure $1 A$ and that of a patient (patient 6) in Figure $1 b$.

The peak heights of ethane were measured, and the amount calculated using a calibration gas mix containing $15.2 \mathrm{ppm}$ ethane (Scott Gases, Plumsteadville, PA). The gas standard was injected every day before the measurement of patients' samples. Within-run coefficient of variation was $<14 \%$, and the recovery of exogenous ethane added to the collection bag was $70 \pm 4 \%$ ( $n$ $=15$ ); thus, the "recovery factor" used $=100 / 70=1.43$. To test the effect of variations in minute ventilation on breath ethane production, a healthy adult volunteer was trained to vary minute ventilation from 8 to $18 \mathrm{~L} / \mathrm{min}$, as measured by a Tissot spirometer (Warren E. Collins Inc., Boston, MA). Breath ethane was $4-$ $5 \mathrm{pmol} / \mathrm{kg} / \mathrm{min}$ when studied at six different ventilation rates within this range, indicating a lack of effect of minute ventilation on breath ethane production.

Ethane production was calculated using the following formula, in which pkhtsamp = peak height of the concentrated sample and pkhtstd $=$ peak height of the standard. The figure $10^{12} \mathrm{pmol}$ ethane $/ 2.24 \times 10^{4} \mathrm{~mL}$ is the specific volume occupied by $1 \mathrm{~mol}$ of gas at normal temperature and pressure (15).

$$
\begin{aligned}
& \text { Ethane pmol } / \mathrm{kg} / \mathrm{min}=\frac{\text { pkhtsamp }}{\mathrm{pkhtstd}} \times \mathrm{ppm} \mathrm{std} \\
& \qquad \begin{aligned}
\times \text { vol samp }(\mathrm{mL}) \times 1.43 \times \frac{10^{12} \mathrm{pmol} \text { ethane }}{2.24 \times 10^{4} \mathrm{~mL}} \\
\quad \div[\text { weight }(\mathrm{kg}) \times \text { min }]
\end{aligned}
\end{aligned}
$$

Statistical analysis. Data are reported as mean \pm SEM. Oneway analysis of variance with Fisher's method for post hoc comparison was used to examine the difference between groups. Regression analysis was used to examine the correlation between the breath ethane and indices of vitamin $\mathrm{E}$ status and liver function tests $(p>0.05=\mathrm{NS})$.

\section{RESULTS}

Controls. Breath ethane values in fasting sibling controls were $34 \pm 12 \mathrm{pmol} / \mathrm{kg} / \mathrm{min}$ and did not differ from postprandial values $(31 \pm 12 \mathrm{pmol} / \mathrm{kg} / \mathrm{min})$. Breath ethane values in fasting sibling controls did not differ from values for healthy controls sampled randomly, in the nonfasted state $(21 \pm 14 \mathrm{pmol}$ ethane/ $\mathrm{kg} / \mathrm{min}$ ). Neither age nor weight had an effect on breath ethane production.

Four children with chronic severe liver disease (a 17-y-old with chronic active hepatitis and three children ages 1,2, and 3 y with biliary atresia) were considered disease controls because they had normal serum vitamin E $(20 \pm 7 \mu \mathrm{g} / \mathrm{mL})$. Modified OVETT in the patient with chronic active hepatitis was normal. Serum selenium was not tested in the 17 -y-old and was below the normal range of $90-170 \mu \mathrm{g} / \mathrm{L}$ in the other three patients $(50-66 \mu \mathrm{g} / \mathrm{L})$. Mean breath ethane for the four children was $47 \pm 16 \mathrm{pmol} / \mathrm{kg} /$ min, a value that did not differ significantly from either that of patients or that of controls.

Patients. Clinical features of the patients are summarized in Table 1. Various measures of vitamin $E$ status are shown in Table 2; as indicated, patients were markedly deficient in vitamin E compared with controls. In patients 5 and 6 , serum vitamin $E$ did not rise above $2 \mu \mathrm{g} / \mathrm{mL}$ during the OVETT. The vitamin Edeficient patients produced more ethane (mean of the two samples in the fast state) than the healthy controls; $78 \pm 10$ versus $26 \pm 9 \mathrm{pmol} / \mathrm{kg} / \mathrm{min}(p<0.001)$ [ethane values for postprandial siblings and healthy child controls were combined because the values did not differ (Fig. 2)\}. In the patients, values for breath 
Table 1. Clinical and biochemical characteristics of patients and healthy controls*

\begin{tabular}{|c|c|c|c|c|c|c|c|c|c|}
\hline Diagnosis (sex) & Age $(y)$ & Wt $(\mathrm{kg})$ & $\begin{array}{c}\text { Duration } \\
\text { vitamin } E \\
\text { deficiency }(\mathrm{y})\end{array}$ & $\begin{array}{c}\text { Serum bilirubin } \\
\text { total } / \text { direct } \\
(\mathrm{mg} / \mathrm{dL})\end{array}$ & $\begin{array}{c}\text { Serum } \\
\text { AST/ALT } \\
(\mathrm{U} / \mathrm{L}) \\
\end{array}$ & $\begin{array}{c}\text { Serum } \gamma \text {-glutamyl } \\
\text { transpeptidase }(\mathrm{U} / \mathrm{L})\end{array}$ & $\begin{array}{l}\text { Serum } \\
\text { albumin } \\
(\mathrm{g} / \mathrm{dL})\end{array}$ & $\begin{array}{c}\text { Serum } \\
\text { selenium } \\
(\mu \mathrm{g} / \mathrm{L})\end{array}$ & Neurologic findings \\
\hline \multicolumn{10}{|l|}{ Vitamin $\mathrm{E}$ deficient patients } \\
\hline 1. Alagille syndrome (f) & 13 & 24.5 & 7 & $10.9 / 8.3$ & $244 / 240$ & 610 & 4.3 & 93 & $\begin{array}{l}\text { Nystagmus, dysmetria, ab- } \\
\text { sent DTR in LE, paraly } \\
\text { sis of upward gaze }\end{array}$ \\
\hline 2. Alagille syndrome (f) & 12 & 22.2 & 5 & $4.4 / 3 / 1$ & $66 / 39$ & 26 & 4.4 & 120 & $\begin{array}{l}\text { Nystagmus, dysmetria, ab- } \\
\text { sent DTR, dysphonia, } \\
\text { wide-base gait }\end{array}$ \\
\hline 3. Alagille syndrome $(f)$ & 11 & 25.0 & 1 & $2.1 / 1 / 2$ & $155 / 164$ & 365 & 4.8 & 156 & Nystagmus, dysmetria \\
\hline 4. Biliary atresia $(\mathrm{f})$ & 1 & 10.3 & 1 & $24.8 / 15.9$ & $202 / 94$ & 90 & 3.0 & 62 & $\begin{array}{l}\text { Wide-based gait, inability to } \\
\text { walk without support }\end{array}$ \\
\hline 5. Chronic hepatitis, cirrhosis (f) & 15 & 47.8 & 6 & $1.7 / 0.8$ & $37 / 29$ & 9 & 3.8 & 104 & $\begin{array}{l}\text { Dysmetria, absent DTR in } \\
\text { LE, wide-based gait, ocu- } \\
\text { lomotor apraxia }\end{array}$ \\
\hline 6. Chronic hepatitis, cirrhosis (m) & 8 & 21.1 & 1 & $13.7 / 9.9$ & $183 / 183$ & 1085 & 4.7 & 93 & Decreased DTR in LE \\
\hline 7. Cystic fibrosis, cirrhosis (m) & 17 & 39.0 & 3 & ND & ND & ND & ND & ND & Normal \\
\hline 8. Cirrhosis, hypoxemia (m) & 17 & 34.4 & 1 & $15.4 / 9.9$ & $156 / 62$ & 286 & 2.4 & 107 & Normal \\
\hline Mean \pm SD & $12 \pm 2$ & $28.0 \pm 8.3$ & & & & & & & \\
\hline Normal values & & & & $\leq 1.5 / \leq 0.5$ & $0-40 / 0-30$ & $0-23$ & $3.2-5.0$ & $90-170$ & \\
\hline \multicolumn{10}{|l|}{ Healthy controls } \\
\hline 1. Sibling (m) & 17 & 76.0 & & & & & & & \\
\hline 2. Sibling (m) & 9 & 25.0 & & & & & & & \\
\hline 3. Sibling $(\mathrm{m})$ & 7 & 23.6 & & & & & & & \\
\hline 4. Sibling $(\mathrm{f})$ & 15 & 55.5 & & & & & & & \\
\hline 5. Sibling (f) & 15 & 64.8 & & & & & & & \\
\hline 6. Well child (f) & 7 & 26.9 & & & & & & & \\
\hline 7. Well child (m) & 5 & 18.9 & & & & & & & \\
\hline 8. Well child (m) & 7 & 32.0 & & & & & & & \\
\hline 9. Well child (m) & 8 & 33.0 & & & & & & & \\
\hline Mean \pm SD & $11 \pm 1$ & $39.9 \pm 6.6$ & & & & & & & \\
\hline
\end{tabular}

* ND, not done; DTR, deep tendon reflexes; LE, lower extremities; AST, aspartate aminotransferase; and ALT, alanine aminotransferase 
a



b

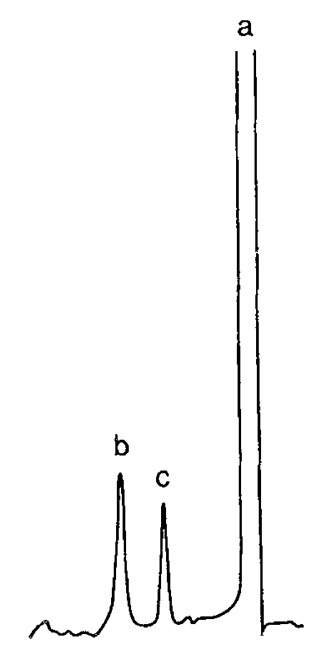

Fig. 1. a, Sample chromatograph of a calibration gas mix containing methane, $15.4 \mathrm{ppm}$, and ethane, $15.2 \mathrm{ppm}$, with the detector temperature at $40^{\circ} \mathrm{C}$ and an attenuation factor of $320 . b$, Sample chromatograph of a concentrated gas sample from a patient (no. 6) run at conditions identical to those in $a$, except that the attenuation factor was 20 . In both chromatographs the peaks are methane $(a)$ and ethane $(b)$. In the patient, peak $c$ is an unidentified peak.

ethane before and after the high fat breakfast were $59 \pm 9$ versus $76 \pm 12 \mathrm{pmol} / \mathrm{kg} / \mathrm{min}$ (NS). Corresponding values for the high carbohydrate breakfast were $79 \pm 13$ versus $46 \pm 11 \mathrm{pmol} / \mathrm{kg} /$ min (NS). Neither age, weight, serum aminotransferases, alkaline phosphatase, nor total or indirect bilirubin correlated with breath ethane.

The parenteral vitamin $E$ therapy normalized at least one measure of vitamin $E$ status in patients $1,2,3$, and 4 during the Pediatric Clinical Research Unit stay. It was necessary to double the initial dose in patient 5 for correction of biochemical indices of vitamin $E$ deficiency. All patients normalized vitamin $E$ status by 9 wk after initiation of therapy; values for the various measures of vitamin $E$ sufficiency in response to chronic therapy are shown in Table 2.

Data for three of the four patients who normalized vitamin $E$ status after the initial injection of vitamin $E$ are summarized in Figure 3. Breath ethane declined significantly from $100 \pm 17$ $\mathrm{pmol} / \mathrm{kg} / \mathrm{min}$ at baseline to $16 \pm 15 \mathrm{pmol} / \mathrm{kg} / \mathrm{min} 44 \mathrm{~h}$ after therapy $(p<0.05)$. Data from the 4 th patient (patient 4) who normalized vitamin E status during the Pediatric Clinical Research Unit stay are shown in Figure 4 . This child had a markedly low concentration of serum selenium $(62 \mu \mathrm{g} / \mathrm{L}$, normal $=90-$ $170 \mu \mathrm{g} / \mathrm{L}$ ). Despite prompt normalization of serum vitamin $\mathrm{E}$, vitamin E:total lipids, and $\mathrm{RBC}$ hemolysis after parenteral $\mathrm{E}$ therapy, breath ethane did not normalize until serum selenium approached normal values in response to administration of oral selenium $(3 \mu \mathrm{g} / \mathrm{kg} / \mathrm{d})$. Serum selenium concentration in the other patients was normal, although patient 8 had been seleniumdeficient and was being treated with oral selenium.

In all other patients, breath ethane values measured after normalization of all indices of vitamin $\mathrm{E}$ status by parenteral vitamin $\mathrm{E}$ on an outpatient basis were comparable to those of controls (Fig. 2). Breath ethane correlated negatively with serum vitamin $\mathrm{E}(r=0.5949, p<0.04)$ and serum vitamin E:total lipids $(r=0.7602, p<0.004)$ and positively with the erythrocyte peroxide hemolysis test $(r=0.7759, p<0.003)$ (Fig. 5).

\section{DISCUSSION}

Our study shows that it is possible to collect, extract, and quantify ethane in the expired breath of infants and children. Contamination of the expired air sample with environmental hydrocarbons was minimized by the washout period using HCFA $(5,14)$. The breath samples were analyzed on the same day of collection to avoid any change in ethane concentration with sample storage (5). The method of concentrating the gas samples before analysis by condensation on cold precolumn has been shown by others to be effective $(14,16)$. In addition, Porasil-C has been shown to be an effective absorbent (17) for volatile hydrocarbons.

In the study of Lemoyne et al. (5), breath pentane output was significantly higher in vitamin E-deficient adults compared with healthy controls, and it was concluded that breath pentane is a sensitive functional test for assessing vitamin E status. Pentane excretion is influenced by ingestion of polyunsaturated fats; the major source of breath pentane in rats is probably dietary linoleate hydroperoxide (18). This hydrocarbon is more rapidly metabolized by the liver than is ethane (19); thus, breath ethane was selected by us as a better reflection of vitamin $E$ status than pentane in children with liver disease. The lack of effect of highfat meal on ethane production can be explained by the relatively small quantity of $n-3$ fatty acids in the meal compared with the amount of those acids in body fat, inasmuch as the n-3 fatty acids are the substrate for ethane production (14).

Our results show that the concentration of ethane in expired air was significantly higher in children with vitamin E deficiency compared with that in healthy children, a finding consistent with results obtained in animal studies $(4,16,20)$. Although Moscarella et al. (21) reported that adults with liver disease did not exhibit increased concentrations of ethane in expired air, ethane production in the children who were vitamin E-sufficient but had chronic liver disease was intermediate between values of vitamin E-deficient patients and healthy controls. There are several possible explanations for this interesting observation. Although it is possible that the children had vitamin E deficiency at the tissue level, it seems unlikely, given the high value for average serum vitamin $E$ in the group. Our data suggests that the presence of severe liver failure may elevate breath ethane production, and that vitamin $\mathrm{E}$ deficiency in this clinical setting further increases ethane production. The three children with biliary atresia in the liver disease control group were all awaiting liver transplantation, as were the two children in the vitamin $\mathrm{E}$ deficiency group (patients 4 and 8 ) who had the highest breath ethane values that we observed (169 and $140 \mathrm{pmol}$ ethane $/ \mathrm{kg} /$ $\mathrm{min})$. On the other hand, the observation that correction of vitamin E deficiency in our six patients (including patient 4) lowered breath ethane to control values despite continued severe liver disease suggests that, in children as well as in adults (21), liver disease per se does not necessarily result in increased ethane production.

The relatively low serum selenium values in the three vitamin E-sufficient liver disease controls might also have contributed to breath ethane values that were intermediate between vitamin $\mathrm{E}$ deficient subjects and controls. The only vitamin E-deficient patient in whom administration of parenteral vitamin $E$ was not followed by a marked decrease in expired ethane was a child who was also selenium deficient. Breath ethane did not decrease to control values in that patient until both serum vitamin $E$ and serum selenium were normal. Administration of parenteral vitamin $\mathrm{E}$ was followed by a marked decrease in expired ethane in all vitamin E-deficient children, except in the child who was also selenium deficient, until both the selenium status and vitamin $E$ 
Table 2. Vitamin $E$ status of patients and controls*

\begin{tabular}{|c|c|c|c|c|c|c|}
\hline & \multicolumn{2}{|c|}{$\begin{array}{l}\text { Serum vitamin } \mathrm{E} \\
\quad(\mu \mathrm{g} / \mathrm{mL})\end{array}$} & \multicolumn{2}{|c|}{$\begin{array}{l}\text { Serum vitamin E: total lipids } \\
\qquad(\mathrm{mg} / \mathrm{g})\end{array}$} & \multicolumn{2}{|c|}{$\begin{array}{c}\text { Red blood cell hemolysis } \\
(\%)\end{array}$} \\
\hline & Pre† & Posti & Pre $\dagger$ & Post & Pre† & Post \\
\hline \multicolumn{7}{|l|}{ Patients } \\
\hline 1 & 1 & 8 & 0.1 & 0.8 & 100 & 1 \\
\hline 2 & 2 & 9 & 0.3 & 1.1 & 100 & 0 \\
\hline 3 & 3 & 12 & 0.3 & 1.2 & 100 & 36 \\
\hline 4 & 2 & 6 & 0.2 & 0.9 & 100 & 1 \\
\hline 5 & 1 & 4 & 0.2 & 0.9 & 100 & 1 \\
\hline 6 & $<1 \S$ & 5 & 0.1 & 0.9 & 96 & 34 \\
\hline 7 & 3 & ND & 0.5 & ND & 41 & ND \\
\hline 8 & 4 & ND & 0.6 & ND & 0 & ND \\
\hline Mean \pm SD & $2 \pm 1 \|$ & $7 \pm 19$ & $0.3 \pm 0.1 \|$ & $1.0 \pm 0.1 \pi$ & $80 \pm 10 \|$ & $6 \pm 1$ \\
\hline \multicolumn{7}{|l|}{ Sibling controls } \\
\hline 1 & 10 & & 2.0 & & ND & \\
\hline 2 & 10 & & 1.6 & & 2 & \\
\hline 3 & 13 & & 2.0 & & ND & \\
\hline 4 & 11 & & 1.1 & & 0 & \\
\hline 5 & 10 & & 2.0 & & 0 & \\
\hline Mean \pm SD & $11 \pm 1$ & & $1.7 \pm 0.1$ & & $1 \pm 1$ & \\
\hline Normal & $5-20$ & & $\begin{array}{l}>0.6 \text { up to } 12 \mathrm{y}^{* *} \\
>0.8>12 \mathrm{y}^{* *}\end{array}$ & & $<20 \%$ & \\
\hline
\end{tabular}

* ND, not done.

$\dagger$ Before parenteral vitamin $\mathrm{E}$.

$\ddagger$ After sufficient parenteral vitamin $E$ to normalize vitamin $E$ status.

$\S 1 \mu \mathrm{g} / \mathrm{mL}$ is the lower limit of detection in this assay.

$\| p<0.001$ pre $v s$ post.

$\uparrow p<0.05$ post $v s$ pre and $v s$ controls.

** Values from Reference 9.

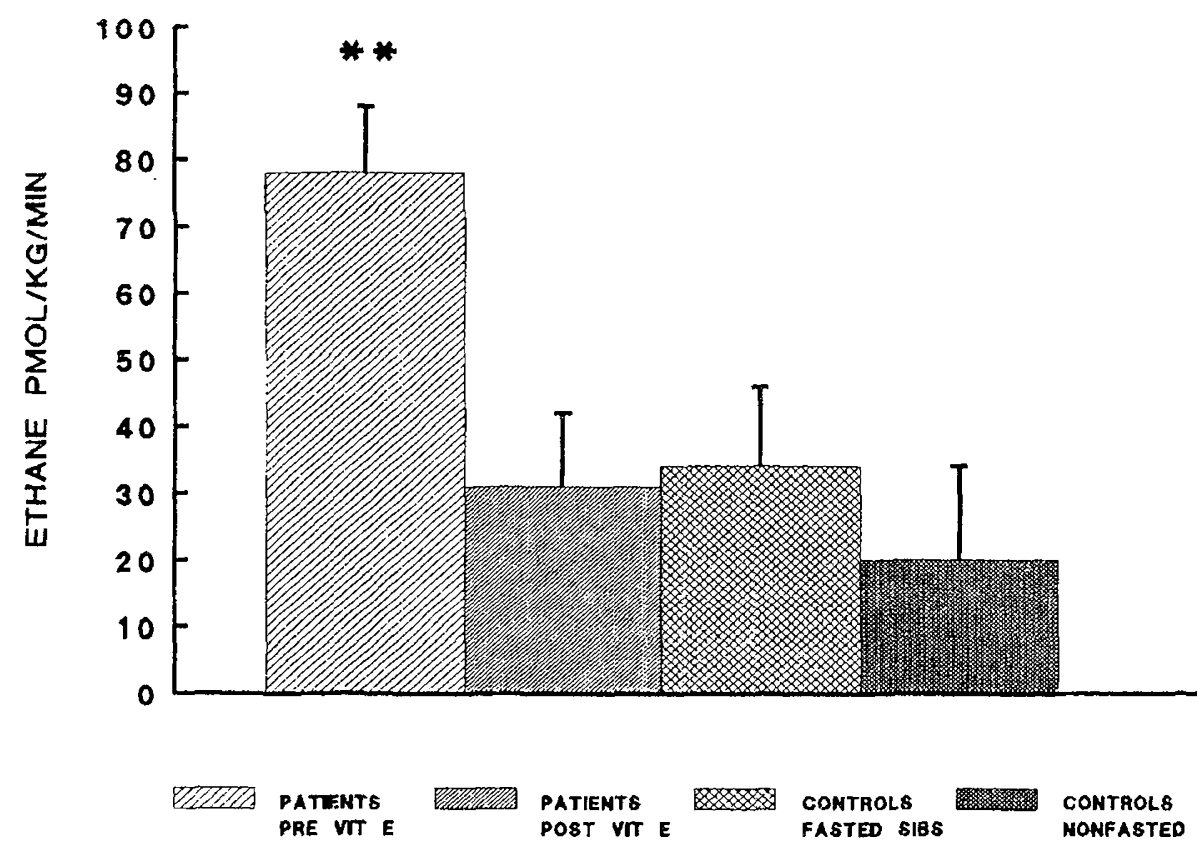

Fig. 2. Breath ethane production in patients before and after normalization of vitamin $E$ status with parenteral vitamin $E$, fasted sibling controls, and healthy children sampled randomly in the nonfasted state. ${ }^{* *}, p<0.01 \mathrm{vs}$ all other groups.

status were normalized. Although there is ample evidence in experimental animals that deficiencies of selenium and vitamin $\mathrm{E}$ are synergistic in promotion of tissue lipid peroxidation, this phenomenon has not to our knowledge been reported in humans. The fact that the child's breath ethane values before therapy with vitamin $\mathrm{E}$ and selenium were the highest that we observed (up to $168 \mathrm{pmol} / \mathrm{kg} / \mathrm{min}$ ) suggests that in this patient the deficiencies of both nutrients may have been synergistic in promoting lipid peroxidation.

The decrease in expired ethane in response to vitamin $\mathrm{E}$ therapy in patients was observed both in the immediate postinjection period (Fig. 2) and in the maintenance phase (Fig. 1). This observation is consistent with the pharmacokinetics of parenterally administered vitamin $\mathrm{E}$, inasmuch as the serum concentration of the vitamin increases significantly within hours of intramuscular injection (22). Parenteral vitamin E decreases the ethane and pentane content of expired air in vitamin Edeficient animals (16). Our findings thus suggest that breath ethane measurements will be useful for following the effect of vitamin $\mathrm{E}$ therapy in children. The significant correlations be- 


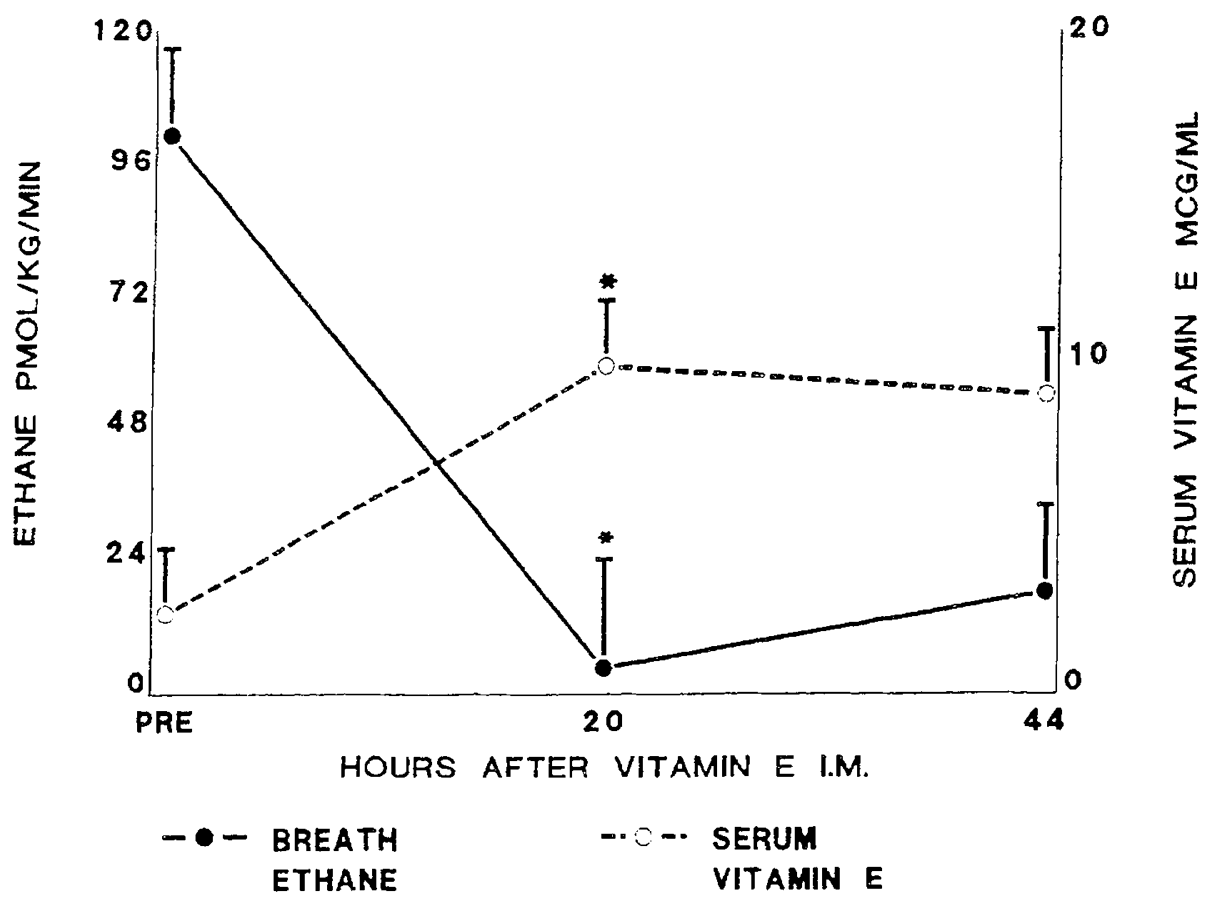

Fig. 3. Breath ethane and serum vitamin $\mathrm{E}$ in patients $1-3$ after the initial intramuscular injection of vitamin $\mathrm{E} .{ }^{*}, p<0.05$ preinjection $v s 20$ and 44-h values.

a. SERUM VITAMIN E

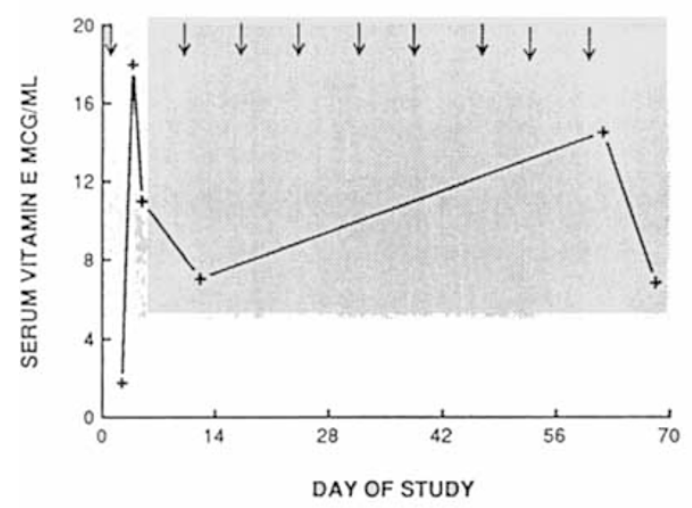

C. SERUM SELENIUM

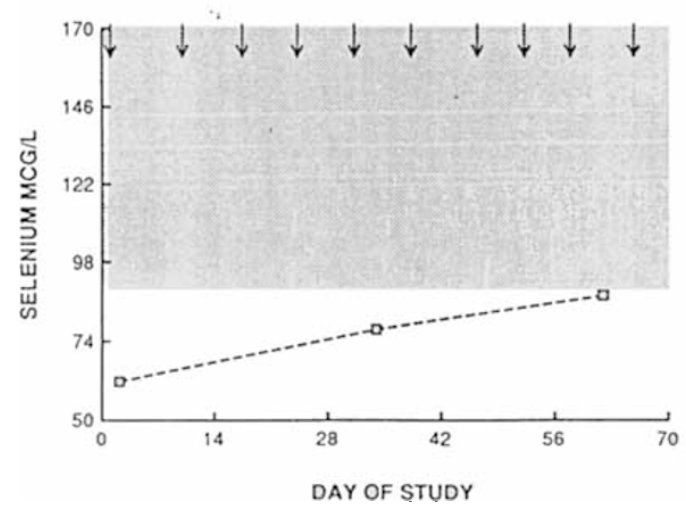

b. RBC HEMOLYSIS

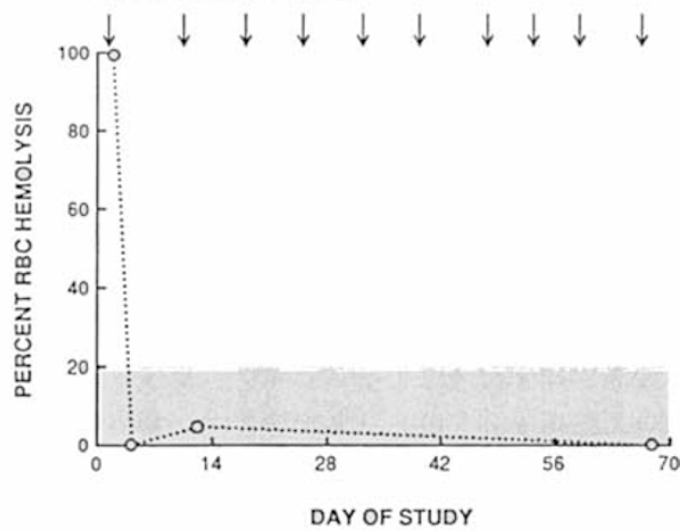

d. BREATH ETHANE

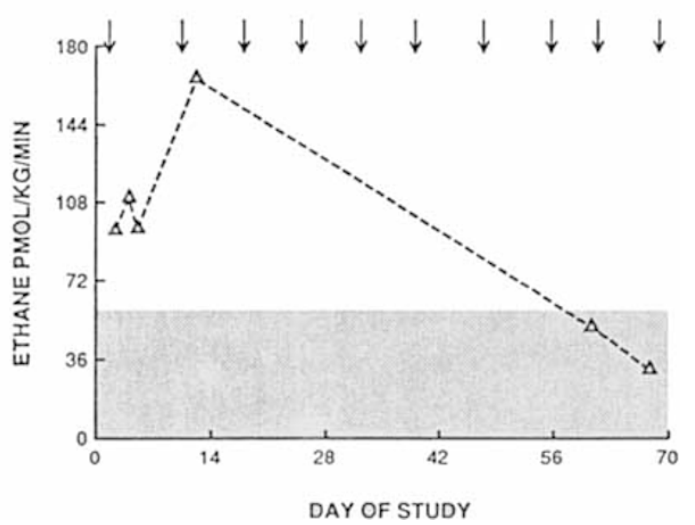

Fig. 4. The effect of parenteral vitamin $\mathrm{E}(5 \mathrm{mg} / \mathrm{kg}$ intramuscularly as indicated by arrows $)$ and selenium $(3 \mu \mathrm{g} / \mathrm{kg} / \mathrm{d}$ p.o. $)$ on breath ethane, various indices of vitamin $\mathrm{E}$ status, and serum selenium in patient 4 . The normal range ( $2 \mathrm{SD}$ above and below the mean) is indicated by the shaded area. 


\section{a. SERUM VITAMIN E}

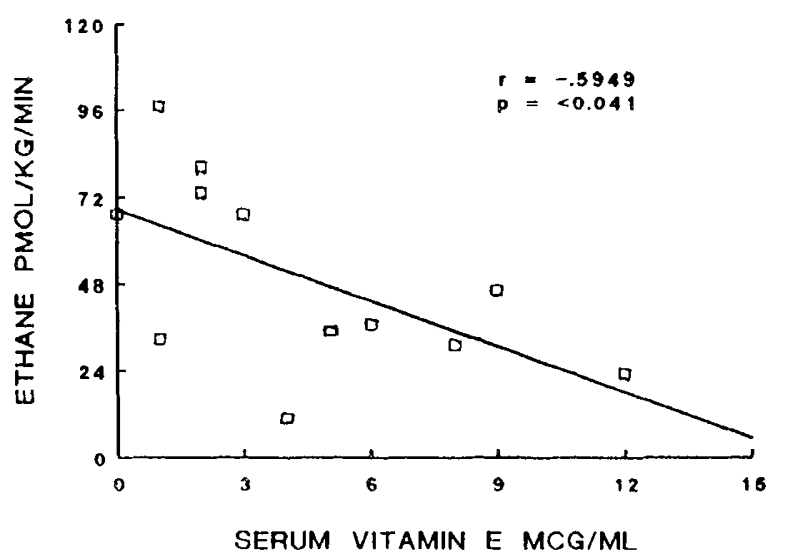

b. SERUM VITAMIN E:TOTAL LIPIDS

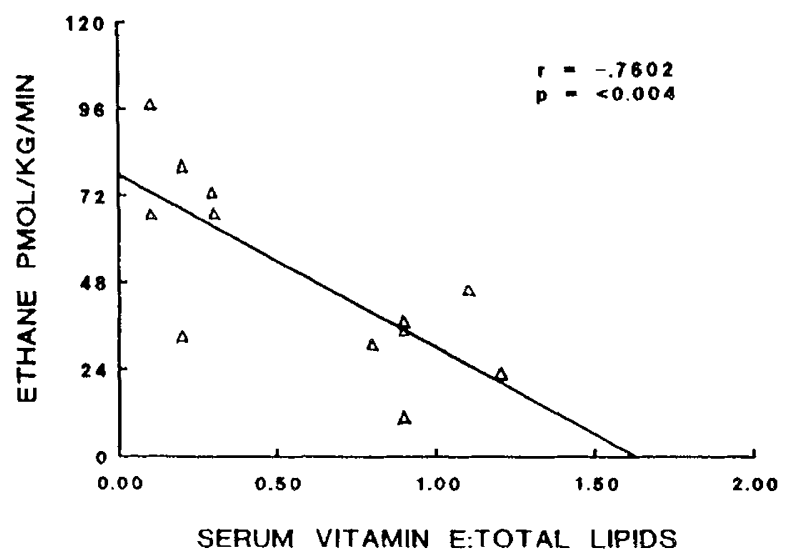

c. PERCENT HEMOLYSIS

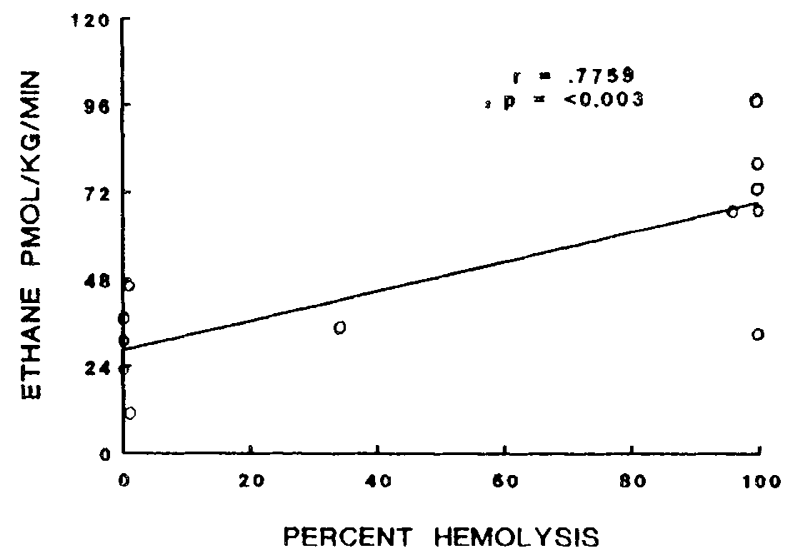

Fig. 5. Correlations between breath ethane and serum vitamin E (a), serum vitamin E:total lipids $(b)$ and the erythroxyte peroxide hemolysis test $(c)$ in patients $1-6$ tested before and after normalization of vitamin $E$ status with parenteral vitamin $E$.

tween breath ethane and serum vitamin E, erythrocyte peroxide hemolysis (thought to be a functional test of vitamin E deficiency) (11), and serum vitamin E:total lipids (thought to be the serum assay that best reflects vitamin E status) (9) provide further support for the utility of the breath test as an index of vitamin $\mathrm{E}$ status.

In summary, this study demonstrates that expired ethane is increased in vitamin E-deficient children compared with controls. This finding suggests that breath ethane measurement is a useful tool to screen for vitamin E deficiency. No children with vitamin E deficiency produced $<25 \mathrm{pmol}$ ethane $/ \mathrm{kg} / \mathrm{min}$, and no vitamin E-sufficient healthy children produced $>74 \mathrm{pmol} /$ $\mathrm{kg} / \mathrm{min}$. Because this overlap exists, a result of $>20 \mathrm{pmol}$ ethane/ $\mathrm{kg} / \mathrm{min}$ would need to be followed up by a serum E:total lipids ratio to confirm vitamin $E$ deficiency, particularly in the presence of severe liver failure, which may elevate breath ethane production. Especially with the introduction of simpler techniques in alkane concentration and small-volume, single-breath samples (23), ethane measurements should prove to be useful in monitoring the response to vitamin E therapy, reducing the frequency of venipunctures usually performed for measurement of serum vitamin $\mathrm{E}$ in this setting. The breath ethane test provides a functional measure of vitamin $E$ status and a means of studying synergism between deficiencies of vitamin $E$ and other antioxidant nutrients such as selenium. The intake of meals high in either fat or carbohydrate did not affect ethane measurements, suggesting that random breath measurement in nonfasted patients could provide useful information.

Acknowledgments. The authors thank Lesia Green for secretarial assistance, Alan Lake, M.D., for referral of patients, and David Shade for assistance with measurements of minute ventilation. We also thank Hoffman LaRoche for provision of $\alpha$ tocopherol acetate.

\section{REFERENCES}

1. Burton GW, Joyce A, Ingold KU 1983 Is vitamin $\mathrm{E}$ the only lipid-soluble chainbreaking anti-oxidant in human plasma and erythrocyte membranes? Arch Biochem Biophys 221:281-290

2. Gross S, Melhorn DK 1972 Vitamin E, red cell lipids and red cell stability in prematurity. Ann NY Acad Sci 203:141-162

3. Cynamon HA, Isenberg JN, Nguyen CH 1985 Erythrocyte malondialdehyde release in vitro: a functional measure of vitamin $\mathrm{E}$ status. Clin Chin Acta UTNB Galveston 151:169-176

4. Dillard CJ, Dumelin EE, Tappel AL 1977 Effect of vitamin E on expiration of pentane and ethane by the rat. Lipids 12:109-114

5. Lemoyne M, VanGossum A, Kurian R, Jeejeebhoy KN 1988 Plasma vitamin $E$ and selenium and breath pentane in home parenteral nutrition patients. Am J Clin Nutr 48:1310-1315

6. Guggenheim M, Jackson V, Lily J, Silverman A 1983 Vitamin E deficiency and neurologic disease in children with cholestasis: a prospective study. $\mathrm{J}$ Pediatr 102:577-579

7. Sokol RJ, Guggenheim MA, Heubin JA, Iannaccone ST, Butler-Simon N 1985 Frequency and clinical progression of the vitamin E deficiency neurologic disorder in children with prolonged neonatal cholestasis. Am J Dis Child 139:1211-1215 
8. Perlmutter D, Gross P, Jones H, Fulton A, Grand A 1987 Intramuscular vitamin $\mathrm{E}$ repletion in children with chronic cholestasis. Am J Dis Child 141:170-174

9. Sokol RJ, Heubi JE, Iannaccone S, Bove KE, Balistreri WF 1984 Vitamin E deficiency with normal serum vitamin $E$ concentrations in children with chronic cholestasis. N Engl J Med 310:1209-1212

10. Zollner N, Kirsch K 1962 A micromethod for lipids using a sulphooxanillin reaction. $Z$ Gesamte Exp Med 135:545-56

11. Gordon HH, Nitowski HM, Cornblath M 1955 Studies of tocopherol deficiency in infants and children 1 . Hemolysis of erythrocytes in hydrogen peroxide. Am J Dis Child 90:669-681

12. Hansen LG, Warwick WJ 1969 A fluorometric micromethod for serum vitamin $A$ and E. Am J Clin Pathol 51:538-54

13. Sokol RJ, Heubi J, Iannaccone ST, Boue KE, Ballistreri WF 1983 Mechanism causing vitamin E deficiency during chronic childhood cholestasis. Gastroenterology 85:1172-1182

14. Wispe JR, Bell EF, Roberts RJ 1985 Assessment of lipid peroxidation in newborn infants and rabbits by measurement of expired ethane and pentane: influence of parenteral lipid infusion. Pediatr Res 19:374-379
15. Diem K 1962 Documents Geigy Scientific Tables, 6th Ed. Geigy Pharmaceuticals, New York, p 247

16. Wispe JR, Knight M, Roberts RJ 1986 Lipid peroxidation in newborn rabbits: effects of oxygen, lipid emulsion and vitamin E. Pediatr Res 20:505-510

17. Wade CR, Van Rig MA 1985 In vivo lipid peroxidation in man as measured by the respiratory excretion of ethane, pentane, and other low-molecularweight hydrocarbons. Anal Biochem 150:1-7

18. Gelmond D, Stein RA, Meed JF 1981 The bacterial origin of rat breath pentane. Biochem Biophys Res Commun 102:932-936

19. Burk RF, Ludden TM 1989 Exhaled alkanes as indices of in vivo lipid peroxidation. Biochem Pharmacol 38:1029-1032

20. Hafeman DG, Hoekstra WG 1977 Protection against carbon tetrachloride induced lipid peroxidation in the rat by dietary vitamin $\mathrm{E}$, selenium and methionine as measured by ethane evolution. I Nutr 107:656-665

21. Moscarella S, Laffi G, Buzzelli G, Mazzanti R, Caramelli L, Gentilini P 1984 Expired hydrocarbons in patients with chronic liver disease. Hepatogastroenterology 31:60-63

22. Colburn WA Ehrenkranz RA 1983 Pharmacokinetics of a single intramuscular injection of vitamin E to premature neonates. Pediatr Pharmacol $3: 7-14$

23. Zarling EJ, Clapper M 1987 Technique for gas chromatographic measurement of volatile alkanes from single-breath samples. Clin Chem 33:140-141 